Article

\title{
Three-Dimensional Mesoporous $\mathrm{Ni}-\mathrm{CeO}_{2}$ Catalysts with $\mathrm{Ni}$ Embedded in the Pore Walls for $\mathrm{CO}_{2}$ Methanation
}

\author{
Luhui Wang ${ }^{1, *(\mathbb{D}}$, Junang Hu ${ }^{1,2}$, Hui Liu ${ }^{3}$, Qinhong Wei ${ }^{1}$, Dandan Gong ${ }^{1}$, Liuye Mo ${ }^{4}$, \\ Hengcong Tao ${ }^{1}$ and Chengyang Zhang ${ }^{1}$ \\ 1 Department of Chemical Engineering, School of Petrochemical Technology and Energy Engineering, \\ Zhejiang Ocean University, Zhoushan 316022, China; hujunang0120@126.com (J.H.); \\ weiqinhong@zjou.edu.cn (Q.W.); dandangong@zjou.edu.cn (D.G.); hengcongtao@zjou.edu.cn (H.T.); \\ zhangchengyang554@126.com (C.Z.) \\ 2 School of Port and Transportation Engineering, Zhejiang Ocean University, Zhoushan 316022, China \\ 3 School of Food and Pharmaceutical, Zhejiang Ocean University, Zhoushan 316022, China; liuhui@zjou.edu.cn \\ 4 Institute of Innovation \& Application, Zhejiang Ocean University, Zhoushan 316022, China; \\ liuyemo@zjou.edu.cn \\ * Correspondence: wangluhui1008@zjou.edu.cn; Tel.: +86-580-255-1050
}

Received: 8 April 2020; Accepted: 6 May 2020; Published: 8 May 2020

\begin{abstract}
Mesoporous Ni-based catalysts with $\mathrm{Ni}$ confined in nanochannels are widely used in $\mathrm{CO}_{2}$ methanation. However, when Ni loadings are high, the nanochannels are easily blocked by nickel particles, which reduces the catalytic performance. In this work, three-dimensional mesoporous $\mathrm{Ni}-\mathrm{CeO}_{2}-\mathrm{CSC}$ catalysts with high Ni loadings (20-80 wt \%) were prepared using a colloidal solution combustion method, and characterized by nitrogen adsorption-desorption, X-ray diffraction (XRD), transmission electron microscopy (TEM) and $\mathrm{H}_{2}$ temperature programmed reduction $\left(\mathrm{H}_{2}-\mathrm{TPR}\right)$. Among the catalysts with different $\mathrm{Ni}$ loadings, the $50 \% \mathrm{Ni}-\mathrm{CeO}_{2}-\mathrm{CSC}$ with $50 \mathrm{wt} \% \mathrm{Ni}$ loading exhibited the best catalytic performance in $\mathrm{CO}_{2}$ methanation. Furthermore, the $50 \% \mathrm{Ni}-\mathrm{CeO}_{2}-\mathrm{CSC}$ catalyst was stable for $50 \mathrm{~h}$ at $300^{\circ}$ and $350{ }^{\circ} \mathrm{C}$ in $\mathrm{CO}_{2}$ methanation. The characterization results illustrate that the $50 \% \mathrm{Ni}-\mathrm{CeO}_{2}-\mathrm{CSC}$ catalyst has Ni particles smaller than $5 \mathrm{~nm}$ embedded in the pore walls, and the $\mathrm{Ni}$ particles interact with $\mathrm{CeO}_{2}$. On the contrary, the $50 \% \mathrm{Ni}-\mathrm{CeO}_{2}-\mathrm{CP}$ catalyst, prepared using the traditional coprecipitation method, is less active and selective for $\mathrm{CO}_{2}$ methanation due to the larger size of the $\mathrm{Ni}$ and $\mathrm{CeO}_{2}$ particles. The special three-dimensional mesoporous embedded structure in the $50 \% \mathrm{Ni}-\mathrm{CeO}_{2}-\mathrm{CSC}$ can provide more metal-oxide interface and stabilize small $\mathrm{Ni}$ particles in pore walls, which makes the catalyst more active and stable in $\mathrm{CO}_{2}$ methanation.
\end{abstract}

Keywords: $\mathrm{CO}_{2}$ methanation; $\mathrm{Ni}-\mathrm{CeO}_{2} ;$ metal-oxide interface; embedded catalyst; colloidal solution combustion

\section{Introduction}

In recent years, $\mathrm{CO}_{2}$ conversion has attracted much attention [1,2]. $\mathrm{CO}_{2}$ methanation can convert $\mathrm{CO}_{2}$ and renewable $\mathrm{H}_{2}$ to storable and transportable $\mathrm{CH}_{4}$, which is of great significance for greenhouse gas control and the chemical storage of renewable $\mathrm{H}_{2}$ [3,4]. Although the exothermic methanation is thermodynamically favorable at low temperatures, there are significant kinetic limitations for converting $\mathrm{CO}_{2}$ into methane due to the stability of $\mathrm{CO}_{2}$.

A large number of studies have shown that the $\mathrm{Rh}$ [5], $\mathrm{Ru}$ [6,7], $\mathrm{Pd}$ [8] and $\mathrm{Ni}$ [9] catalysts are active in $\mathrm{CO}_{2}$ methanation. Precious metal catalysts have a higher activity than Ni catalysts, but the high cost of precious metal catalysts limits their large-scale application in industry. Ni catalysts 
have a relatively low cost and have attracted extensive attention in the field of $\mathrm{CO}_{2}$ methanation. To improve the methanation activity of $\mathrm{Ni}$ catalysts, many methods have been proposed to prepare highly dispersed Ni catalysts [10-14]. The general strategy to improve the dispersion of $\mathrm{Ni}$ is to load the Ni onto a support with a high specific surface area [15-17]. However, small particles of Ni with high dispersion tend to aggregate and grow into large particles in a long-time reaction, leading to catalyst deactivation $[11,18]$. Embedded structures can improve the thermal stability of Ni-based catalysts. Embedded Ni catalysts, such as Ni@HZSM-5 [19], Ni@MOF [20,21] and Ni@C [22], have been used for carbon dioxide methanation and shown good stability.

Mesoporous materials are widely used to prepare embedded catalysts [23-26]. Metal particles can be embedded in the pore channels [25] or pore walls [27]. Metal particles embedded in the pore channels are a conventional structure of embedded catalysts, but the high metal load can lead to channel blockage, which is not conducive to mass transfer [26]. On the contrary, the metal particles embedded in the pore wall can not only improve the thermal stability of the catalyst, but also avoid the blockage of the channel, which is conducive to mass transfer. Moreover, the metal particles embedded in the pore wall are in close contact with the support and have abundant metal-support interfaces, which is conducive to improving the methanation activity [28].

As $\mathrm{CeO}_{2}$ can adsorb and activate $\mathrm{CO}_{2}, \mathrm{Ni}-\mathrm{CeO}_{2}$ catalysts prepared by different methods have been applied to $\mathrm{CO}_{2}$ methanation and exhibit excellent catalytic performance [28-32]. Small nickel particles and abundant $\mathrm{Ni}-\mathrm{CeO}_{2}$ interfaces are important for improving the carbon dioxide activity of the catalyst [28,32]. Recently, a facial colloidal solution combustion (CSC) method was reported for the synthesis of three-dimensional mesoporous materials [33-35]. In this paper, in order to increase the $\mathrm{Ni}-\mathrm{CeO}_{2}$ interface and improve the thermal stability of a highly dispersed $\mathrm{Ni}-\mathrm{CeO}_{2}$ catalyst, three-dimensional mesoporous $\mathrm{Ni}-\mathrm{CeO}_{2}-\mathrm{CSC}$ catalysts with $\mathrm{Ni}$ embedded in the pore walls were prepared using a colloidal solution combustion method. The catalysts had abundant metal-support interfaces and small nickel particles, showing good catalytic performance in $\mathrm{CO}_{2}$ methanation.

\section{Results and Discussion}

\subsection{Characterization of Fresh and Reduced Catalysts}

The $\mathrm{N}_{2}$ adsorption-desorption isotherms and pore size distributions of the fresh $\mathrm{Ni}-\mathrm{CeO}_{2}-\mathrm{CSC}$ catalysts are shown in Figure 1. As shown in Figure 1a, all the catalysts display type IV isotherms with a hysteresis loop, indicating the presence of a mesoporous structure. When the relative pressure $\left(\mathrm{P} / \mathrm{P}_{0}\right)$ approaches 1 , the adsorption branch of the isotherm rises, which is due to the adsorption of nitrogen in the macropore. This indicates that a certain amount of macropore exists in these catalysts. In Figure 1b, all the catalysts exhibit a probable pore diameter centered at $20-25 \mathrm{~nm}$. The probable pore diameter is similar to that of the colloidal $\mathrm{SiO}_{2}$ (about $22 \mathrm{~nm}$ ) used to prepare the catalyst, indicating that the mesoporous structure is mainly produced by etching the $\mathrm{SiO}_{2}$ particles.
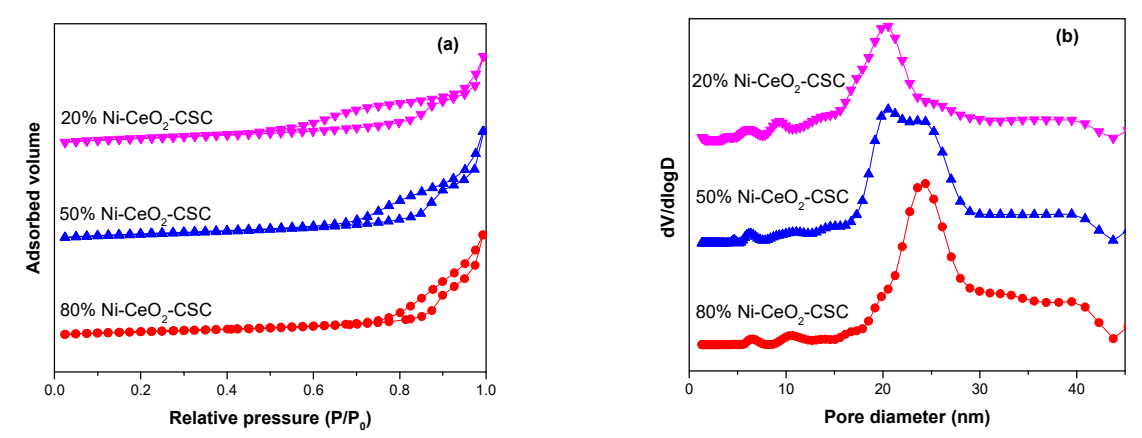

Figure 1. (a) $\mathrm{N}_{2}$ adsorption-desorption isotherms and (b) pore size distributions of the fresh $\mathrm{Ni}-\mathrm{CeO}_{2}-\mathrm{CSC}$ catalysts. 
Table 1 lists the Brunauer-Emmett-Teller $(\mathrm{BET})$ surface areas $\left(\mathrm{S}_{\mathrm{BET}}\right)$ of the fresh $\mathrm{Ni}-\mathrm{CeO}_{2}$ catalysts prepared by the CSC and coprecipitation $(\mathrm{CP})$ methods. For the mesoporous $\mathrm{Ni}-\mathrm{CeO}_{2}-\mathrm{CSC}$ catalysts, the $\mathrm{S}_{\mathrm{BET}}$ of the catalyst decreases with the increase in nickel content. The $\mathrm{S}_{\mathrm{BET}}$ of the $50 \% \mathrm{Ni}-\mathrm{CeO}_{2}-\mathrm{CSC}$ is $121.5 \mathrm{~m}^{2} / \mathrm{g}$, which is more than three times that of the $50 \% \mathrm{Ni}-\mathrm{CeO}_{2}-\mathrm{CP}$ catalyst prepared by the coprecipitation method. The results show that the mesoporous $\mathrm{Ni}-\mathrm{CeO}_{2}-\mathrm{CSC}$ catalysts have larger $\mathrm{S}_{\mathrm{BETs}}$ than the $50 \% \mathrm{Ni}-\mathrm{CeO}_{2}-\mathrm{CP}$ catalyst.

Table 1. Physicochemical properties of the fresh $\mathrm{Ni}-\mathrm{CeO}_{2}$.

\begin{tabular}{cccc}
\hline Samples & $\mathbf{S}_{\mathbf{B E T}}\left(\mathbf{m}^{\mathbf{2}} \mathbf{g}\right)$ & $\mathbf{C e O}_{\mathbf{2}}(\mathbf{n m})^{\mathbf{a}}$ & $\left.\mathbf{N i O}^{\mathbf{a} m}\right)^{\mathbf{a}}$ \\
\hline $20 \% \mathrm{Ni}^{-} \mathrm{CeO}_{2}-\mathrm{CSC}$ & 134.0 & 3.9 & $/^{\mathrm{b}}$ \\
$50 \% \mathrm{Ni}-\mathrm{CeO}_{2}-\mathrm{CSC}$ & 121.5 & 3.1 & $/^{\mathrm{b}}$ \\
$80 \% \mathrm{Ni}-\mathrm{CeO}_{2}-\mathrm{CSC}$ & 94.9 & $/^{\mathrm{b}}$ & 3.7 \\
$50 \% \mathrm{Ni}-\mathrm{CeO}_{2}-\mathrm{CP}$ & 38.7 & 8.2 & 8.9 \\
\hline
\end{tabular}

a Crystal size was calculated using the Scherrer equation according to the XRD result. ${ }^{\mathrm{b}}$ The diffraction peak is too weak.

The X-ray diffraction patterns of the fresh $\mathrm{Ni}-\mathrm{CeO}_{2}$ are shown in Figure $2 \mathrm{a}$. The fresh $20 \%$ $\mathrm{Ni}-\mathrm{CeO}_{2}-\mathrm{CSC}$ exhibits the characteristic diffraction peaks of $\mathrm{CeO}_{2}$, and no peaks of $\mathrm{NiO}$ are observed. The broad diffraction peaks and low intensity could indicate small crystallites or solids with low crystallinity, such as amorphous phase. From the following HRTEM image, we found small crystallites, and no amorphous phase was observed. Therefore, the broad diffraction peaks and low intensity are due to the small crystallites. The XRD result indicates that $\mathrm{NiO}$ is highly dispersed in the $20 \%$ $\mathrm{Ni}-\mathrm{CeO}_{2}-\mathrm{CSC}$ catalyst. When the $\mathrm{Ni}$ loading increased to $50 \%$, the weak and broad diffraction peaks of $\mathrm{CeO}_{2}$ and $\mathrm{NiO}$ were observed, indicating that $\mathrm{NiO}$ and $\mathrm{CeO}_{2}$ particle sizes are small in the catalyst. The $80 \% \mathrm{Ni}-\mathrm{CeO}_{2}-\mathrm{CSC}$ catalyst exhibits an obvious $\mathrm{NiO}$ diffraction peak, and no peaks of $\mathrm{CeO}_{2}$ are observed in the catalyst. The $50 \% \mathrm{Ni}^{-} \mathrm{CeO}_{2}-\mathrm{CP}$ catalyst shows sharp diffraction peaks of $\mathrm{NiO}$ and $\mathrm{CeO}_{2}$, indicating that the $50 \% \mathrm{Ni}-\mathrm{CeO}_{2}-\mathrm{CP}$ catalyst has large $\mathrm{NiO}$ and $\mathrm{CeO}_{2}$ crystal particles.

Table 1 presents the crystal sizes of $\mathrm{NiO}$ and $\mathrm{CeO}_{2}$ calculated by the Scherrer equation. The sizes in the $\mathrm{Ni}-\mathrm{CeO}_{2}-\mathrm{CSC}$ catalyst are less than $5 \mathrm{~nm}$. When the $\mathrm{Ni}$ loading is less than or equal to $50 \%$, the diffraction peak of the $\mathrm{NiO}$ in the $\mathrm{Ni}-\mathrm{CeO}_{2}-\mathrm{CSC}$ is too weak to calculate the crystal size. Even when the nickel content reaches $80 \%$, the average $\mathrm{NiO}$ size is only $3.7 \mathrm{~nm}$. In contrast, the $\mathrm{NiO}$ and $\mathrm{CeO}_{2}$ size in the $50 \% \mathrm{Ni}^{-} \mathrm{CeO}_{2}-\mathrm{CP}$ catalyst are 8.2 and $8.9 \mathrm{~nm}$, respectively. The results indicate that the colloidal solution combustion is an effective method for preparing highly dispersed $\mathrm{Ni}-\mathrm{CeO}_{2}$ catalysts with $\mathrm{NiO}$ and $\mathrm{CeO}_{2}$ particles smaller than $5 \mathrm{~nm}$.
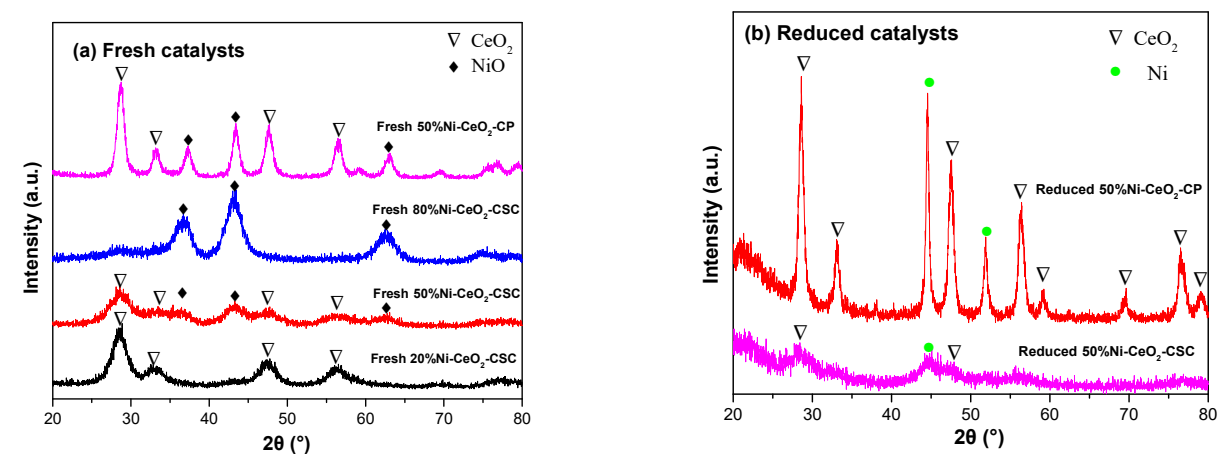

Figure 2. X-ray diffraction (XRD) patterns of $\mathrm{Ni}-\mathrm{CeO}_{2}$ : (a) fresh catalysts, (b) reduced catalysts.

The XRD patterns of the reduced $50 \% \mathrm{Ni}-\mathrm{CeO}_{2}-\mathrm{CSC}$ and $50 \% \mathrm{Ni}-\mathrm{CeO}_{2}-\mathrm{CP}$ are shown in Figure $2 \mathrm{~b}$. The reduced $50 \% \mathrm{Ni}^{-} \mathrm{CeO}_{2}-\mathrm{CP}$ presents sharp Ni peaks, indicating that the crystal size of the $\mathrm{Ni}$ in it was large. Table 2 shows that the $\mathrm{Ni}$ size of the reduced $50 \% \mathrm{Ni}-\mathrm{CeO}_{2}-\mathrm{CP}$ was $24.8 \mathrm{~nm}$, which is 2.8 times the $\mathrm{NiO}$ size of the fresh catalyst. This indicates that the Ni particles were unstable and 
sintered in the process of catalyst reduction, thus forming large Ni particles. For the reduced $50 \%$ $\mathrm{Ni}-\mathrm{CeO}_{2}-\mathrm{CSC}$ catalyst, the crystal size of the $\mathrm{Ni}$ cannot be calculated using the Scherrer equation because the diffraction peaks of the $\mathrm{Ni}$ are too weak, suggesting that the particle size of the $\mathrm{Ni}$ is small. The results indicate that the $50 \% \mathrm{Ni}-\mathrm{CeO}_{2}-\mathrm{CSC}$ catalyst is more stable than the $50 \% \mathrm{Ni}-\mathrm{CeO}_{2}-\mathrm{CSC}$ catalyst in the reduction process.

Table 2. Cristal size of the reduced $50 \% \mathrm{Ni}-\mathrm{CeO}_{2}$ catalysts.

\begin{tabular}{|c|c|c|}
\hline Catalysts & $\mathrm{CeO}_{2}(\mathrm{~nm})^{\mathrm{a}}$ & $\mathrm{Ni}(\mathrm{nm})^{\mathrm{a}}$ \\
\hline Reduced $50 \% \mathrm{Ni}-\mathrm{CeO}_{2}-\mathrm{CSC}$ & 3.2 & $/^{b}$ \\
\hline Reduced $50 \% \mathrm{Ni}-\mathrm{CeO}_{2}-\mathrm{CP}$ & 11.8 & 24.8 \\
\hline
\end{tabular}

The transmission electron microscopy (TEM) images of the colloidal $\mathrm{SiO}_{2}$ and the $50 \%$ $\mathrm{Ni}-\mathrm{CeO}_{2}-\mathrm{CSC}$ are shown in Figure 3. As shown in Figure 3a, the spherical colloidal $\mathrm{SiO}_{2}$ is about $22 \mathrm{~nm}$ in diameter.

Figure $3 b, c$ present the TEM images of the fresh $50 \% \mathrm{Ni}-\mathrm{CeO}_{2}-\mathrm{CSC}$. For the fresh $50 \% \mathrm{Ni}-\mathrm{CeO}_{2}-\mathrm{CSC}$ catalyst, an ordered mesopore of about $20 \mathrm{~nm}$ in diameter is observed in Figure $3 \mathrm{~b}$. During the catalyst preparation, the mesoporous structure was formed after etching the $\mathrm{SiO}_{2}$. The diameter of the mesopore is basically the same as that of the colloidal $\mathrm{SiO}_{2}$. Figure $3 \mathrm{c}$ shows that the pore wall thickness is about $5 \mathrm{~nm}$, and the pore wall is composed of nanoparticles smaller than $5 \mathrm{~nm}$. This is consistent with the $\mathrm{XRD}$ results. Figure $3 \mathrm{~d}$ reveals that the pore wall contains small $\mathrm{NiO}$ and $\mathrm{CeO}_{2}$ particles. As shown in Figure 3d, the particles with a d-spacing of 0.312 and $0.209 \mathrm{~nm}$ are associated with $\mathrm{CeO}_{2}(111)$ and $\mathrm{NiO}(200)$ planes, respectively. These results indicate that the $\mathrm{NiO}$ in the mesoporous $50 \% \mathrm{Ni}-\mathrm{CeO}_{2}-\mathrm{CSC}$ catalyst is embedded in the pore wall rather than filled in the pore channel.

Figure $3 \mathrm{e}$,f present the TEM images of the reduced $50 \% \mathrm{Ni}^{-} \mathrm{CeO}_{2}-\mathrm{CSC}$ catalyst. Figure $3 \mathrm{e}$ shows the mesoporous structure of the reduced catalyst, indicating that the mesoporous structure is stable during the reduction process. As shown in Figure 3f, small particles of Ni embedded in the pore wall are in close contact with $\mathrm{CeO}_{2}$, which can provide more $\mathrm{Ni}-\mathrm{CeO}_{2}$ interface and is conducive to improving the $\mathrm{CO}_{2}$ methanation activity [32].

Figure 4 shows the $\mathrm{H}_{2}$ programmed temperature reduction $\left(\mathrm{H}_{2}-\mathrm{TPR}\right)$ profiles of the $\mathrm{NiO}$ and $\mathrm{Ni}-\mathrm{CeO}_{2}$ catalysts. $\mathrm{NiO}$ was prepared by calcining nickel nitrate hexahydrate at $450{ }^{\circ} \mathrm{C}$ for $4 \mathrm{~h}$. For pure $\mathrm{NiO}$, only one hydrogen consumption peak located at $355^{\circ} \mathrm{C}$ was observed. Combined with the XRD characterization results, the reduction peak at $403^{\circ} \mathrm{C}$ of the $50 \% \mathrm{Ni}-\mathrm{CeO}_{2}-\mathrm{CP}$ can be assigned to the reduction in the large $\mathrm{NiO}$ particles that interacted weakly with $\mathrm{CeO}_{2}$ [32]. However, the $\mathrm{Ni}^{-} \mathrm{CeO}_{2}-\mathrm{CSC}$ catalysts exhibit a broad peak between 300 and $600{ }^{\circ} \mathrm{C}$, which is attributed to the reduction in the surface $\mathrm{CeO}_{2}$ and the small $\mathrm{NiO}$ particles that interacted with $\mathrm{CeO}_{2}[36]$.

Because of the low nickel content, the reduction peak of the $20 \% \mathrm{Ni}-\mathrm{CeO}_{2}-\mathrm{CSC}$ catalyst is small. In addition, the reduction temperature of the catalyst is higher, which may be because the nickel particles in the catalyst were smaller and the interaction with $\mathrm{CeO}_{2}$ was stronger. Shan et al. reported that the highly dispersed $\mathrm{NiO}$ strongly interacted with $\mathrm{CeO}_{2}$ and had a higher reduction temperature [36].

Compared with the $50 \% \mathrm{Ni}-\mathrm{CeO}_{2}-\mathrm{CP}$, the $\mathrm{Ni}-\mathrm{CeO}_{2}-\mathrm{CSC}$ catalysts exhibit an obviously higher reduction temperature, indicating that the $\mathrm{Ni}-\mathrm{CeO}_{2}$ interaction in the $\mathrm{Ni}-\mathrm{CeO}_{2}-\mathrm{CSC}$ is stronger. The strong interaction in the $\mathrm{Ni}-\mathrm{CeO}_{2}-\mathrm{CSC}$ catalysts could be due to the small $\mathrm{NiO}$ particles embedded in the pore wall and in contact with $\mathrm{CeO}_{2}$.

In previous reports, it has been shown that $\mathrm{Ni}^{2+}$ can be incorporated into the $\mathrm{CeO}_{2}$ lattice and form a $\mathrm{Ce}_{1-\mathrm{x}} \mathrm{Ni}_{\mathrm{x}} \mathrm{O}_{2}$ solid solution, which leads to the formation of an oxygen vacancy [36]. The oxygen adsorbed on the oxygen vacancy in the solid solution can be reduced below $300^{\circ} \mathrm{C}[32,36,37]$. However, in the TPR patterns shown in Figure 4, there is no obvious reduction peak below $300^{\circ} \mathrm{C}$, which indicates that it is difficult to generate a solid solution in our $\mathrm{Ni}-\mathrm{CeO}_{2}$ catalysts. 

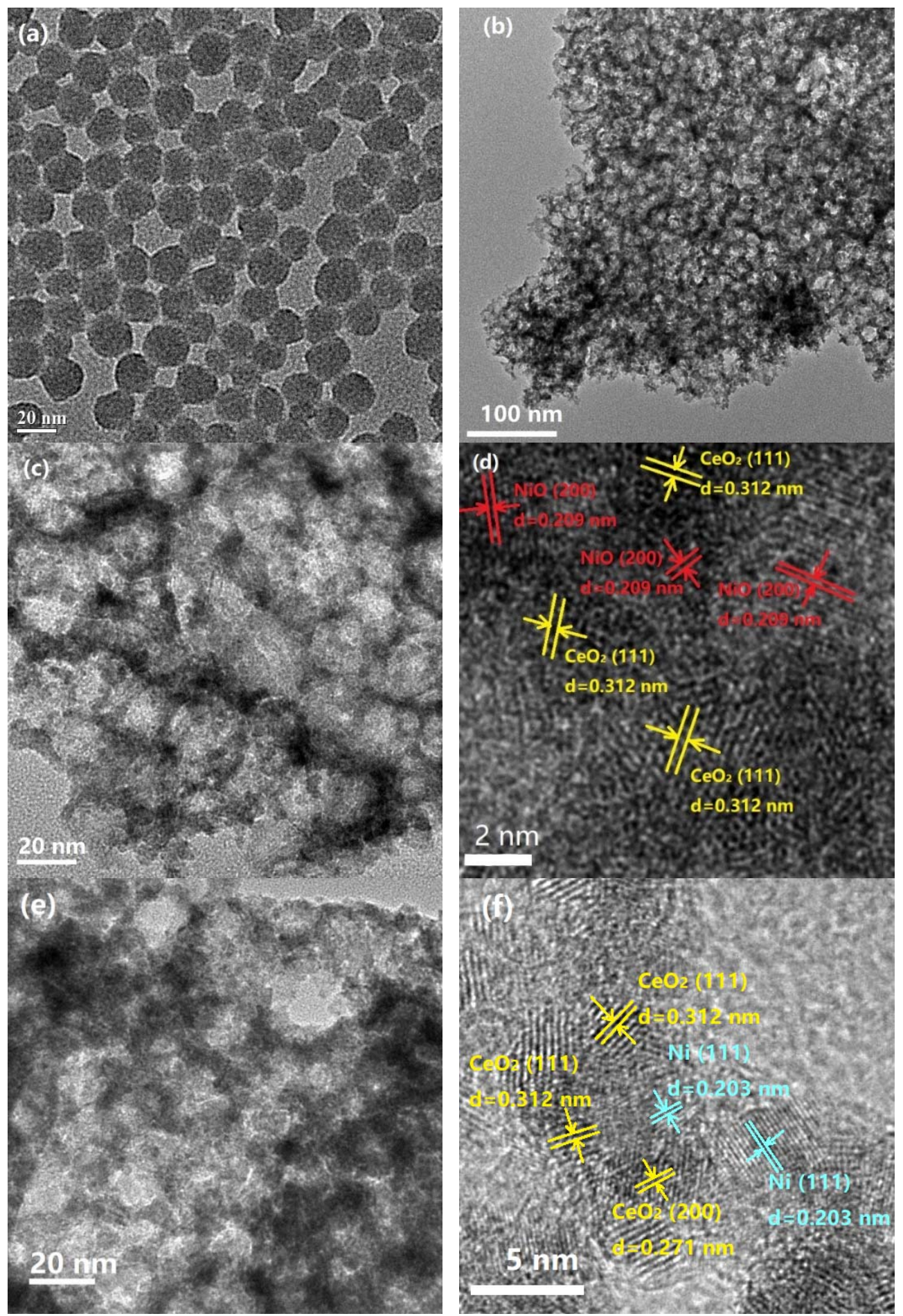

Figure 3. Transmission electron microscopy images of (a) the colloidal $\mathrm{SiO}_{2}$, (b-d) the fresh $50 \%$ $\mathrm{Ni}-\mathrm{CeO}_{2}-\mathrm{CSC}$ and $(\mathbf{e}, \mathbf{f})$ the reduced $50 \% \mathrm{Ni}-\mathrm{CeO}_{2}-\mathrm{CSC}$. 


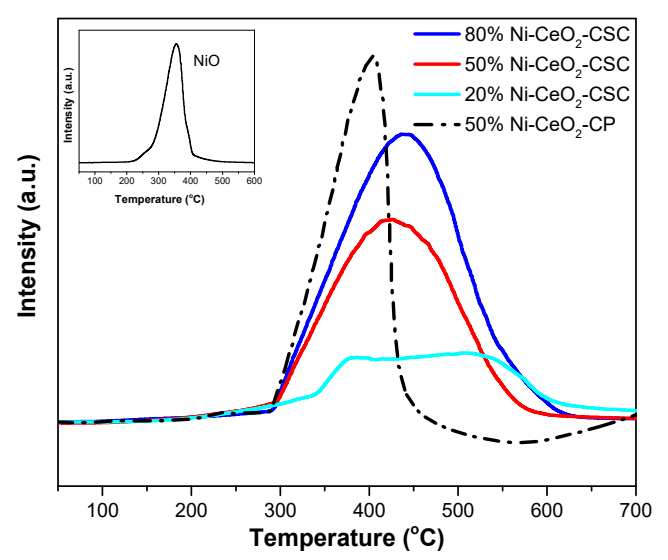

Figure 4. $\mathrm{H}_{2}$ programmed temperature reduction profiles of the $\mathrm{NiO}$, the $50 \% \mathrm{Ni}-\mathrm{CeO}_{2}-\mathrm{CP}$ and the $\mathrm{Ni}-\mathrm{CeO}_{2}-\mathrm{CSC}$.

\subsection{Catalytic Performance}

Figure 5 shows the catalytic performance of the $\mathrm{Ni}-\mathrm{CeO}_{2}-\mathrm{CSC}$ catalysts. At low temperatures, the $\mathrm{CO}_{2}$ conversion and $\mathrm{CH}_{4}$ selectivity of the $20 \% \mathrm{Ni}-\mathrm{CeO}_{2}-\mathrm{CSC}$ catalyst were low. This could be due to most of the $\mathrm{Ni}$ surface being covered by $\mathrm{CeO}_{2}$ in the $20 \% \mathrm{Ni}-\mathrm{CeO}_{2}-\mathrm{CSC}$ catalyst. When the nickel content increased from $20 \%$ to $50 \%$, the $\mathrm{CO}_{2}$ conversion and $\mathrm{CH}_{4}$ selectivity of the $\mathrm{Ni}-\mathrm{CeO}_{2}-\mathrm{CSC}$ increased significantly. When the nickel content further increased to $80 \%$, the conversion and selectivity of the catalyst decreased. The Ni-CSC catalyst with $100 \%$ Ni content showed low $\mathrm{CO}_{2}$ conversion and $\mathrm{CH}_{4}$ selectivity, especially at low temperatures. The $50 \% \mathrm{Ni}-\mathrm{CeO}_{2}-\mathrm{CSC}$ catalyst had the best catalytic performance among the $\mathrm{Ni}-\mathrm{CeO}_{2}-\mathrm{CSC}$ catalysts. At temperatures higher than $400{ }^{\circ} \mathrm{C}$, the conversion and selectivity of the catalyst decreased slightly, due to the limitation of the thermodynamic equilibrium of $\mathrm{CO}_{2}$ methanation and the formation of $\mathrm{CO}$ in the reverse water-gas shift reaction $[38,39]$.
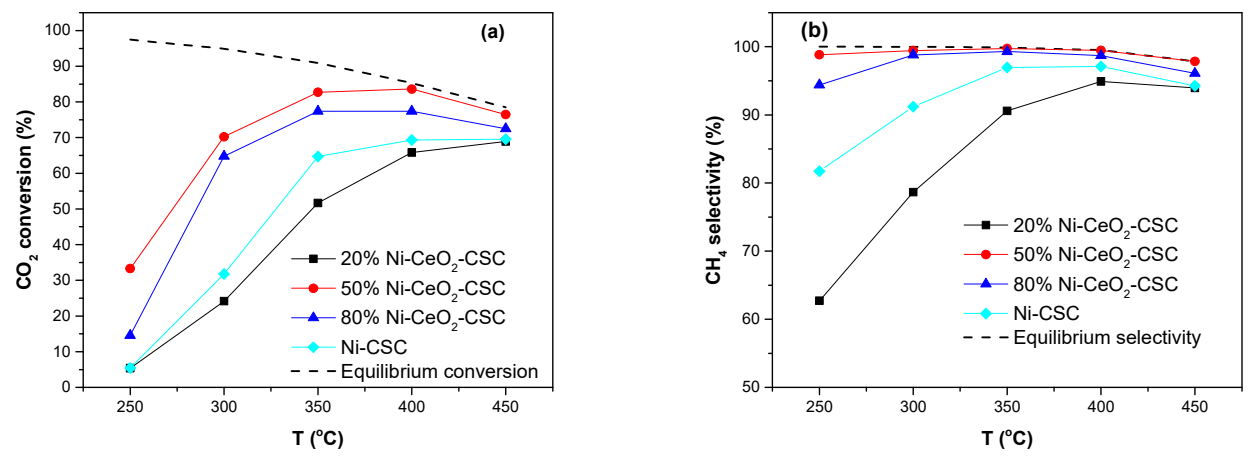

Figure 5. (a) $\mathrm{CO}_{2}$ conversion and (b) $\mathrm{CH}_{4}$ selectivity of the $\mathrm{Ni}-\mathrm{CeO}_{2}-\mathrm{CSC}$ catalysts in $\mathrm{CO}_{2}$ methanation.

The comparison of the catalytic activities of the $50 \% \mathrm{Ni}-\mathrm{CeO}_{2}-\mathrm{CP}$ and $50 \% \mathrm{Ni}-\mathrm{CeO}_{2}-\mathrm{CSC}$ catalysts is shown in Figure 6. Compared with the $50 \% \mathrm{Ni}-\mathrm{CeO}_{2}-\mathrm{CP}, 50 \% \mathrm{Ni}-\mathrm{CeO}_{2}-\mathrm{CSC}$ had a higher $\mathrm{CO}_{2}$ conversion and $\mathrm{CH}_{4}$ selectivity in the temperature range of 250 to $450{ }^{\circ} \mathrm{C}$. At $250{ }^{\circ} \mathrm{C}$, the $\mathrm{CO}_{2}$ conversions of the $50 \% \mathrm{Ni}-\mathrm{CeO}_{2}-\mathrm{CSC}$ and the $50 \% \mathrm{Ni}-\mathrm{CeO}_{2}-\mathrm{CP}$ were $33 \%$ and $4 \%$, respectively. The former is about eight times the latter, indicating that the $50 \% \mathrm{Ni}-\mathrm{CeO}_{2}-\mathrm{CSC}$ catalyst has better low-temperature activity. 

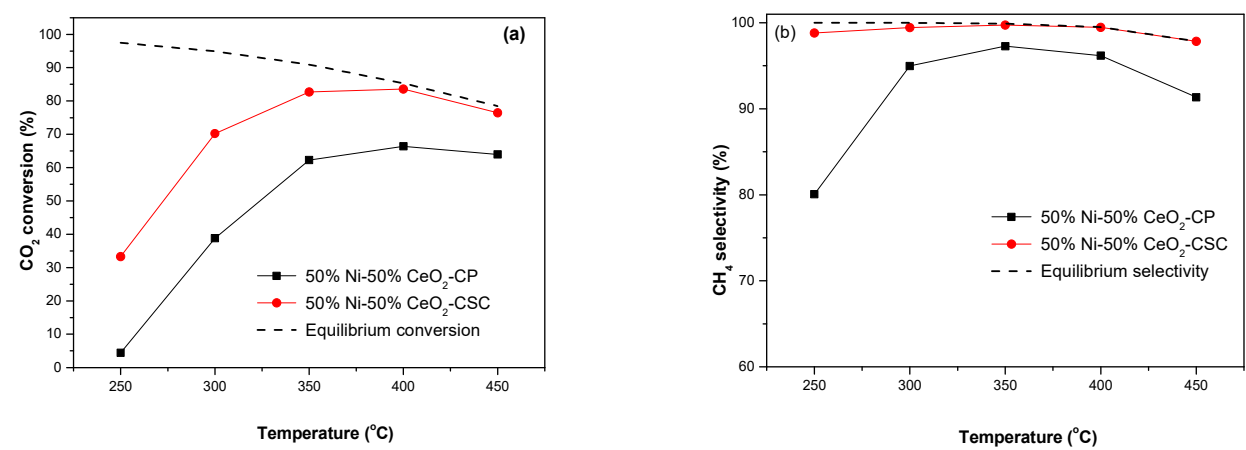

Figure 6. (a) $\mathrm{CO}_{2}$ conversion and (b) $\mathrm{CH}_{4}$ selectivity over the $50 \% \mathrm{Ni}-\mathrm{CeO}_{2}-\mathrm{CSC}$ and $50 \% \mathrm{Ni}-\mathrm{CeO}_{2}-\mathrm{CP}$ catalysts in $\mathrm{CO}_{2}$ methanation.

Small Ni particles can absorb and dissociate $\mathrm{H}_{2}$, and $\mathrm{CeO}_{2}$ can absorb and activate $\mathrm{CO}_{2}$. The $\mathrm{Ni}-\mathrm{CeO}_{2}$ interface facilitates further reactions between the two adsorbed species to form methane [32]. The three-dimensional mesoporous catalyst prepared by the CSC method can keep the particle size of the $\mathrm{Ni}$ and $\mathrm{CeO}_{2}$ less than $5 \mathrm{~nm}$ in the catalyst with a high $\mathrm{Ni}$ content, and at the same time the $\mathrm{Ni}$ embedded in the pore wall provides an abundant $\mathrm{Ni}-\mathrm{CeO}_{2}$ interface, meaning that the $50 \% \mathrm{Ni}-\mathrm{CeO}_{2}-\mathrm{CSC}$ catalyst has excellent activity and selectivity for $\mathrm{CO}_{2}$ methanation. On the contrary, due to the larger size of the $\mathrm{Ni}$ and $\mathrm{CeO}_{2}$ particles, the $50 \% \mathrm{Ni}-\mathrm{CeO}_{2}-\mathrm{CP}$ catalyst is less active and selective for $\mathrm{CO}_{2}$ methanation. The excellent catalytic performance of the $50 \% \mathrm{Ni}-\mathrm{CeO}_{2}-\mathrm{CSC}$ catalyst is related to the large number of small $\mathrm{Ni}$ particles and abundant $\mathrm{Ni}-\mathrm{CeO}_{2}$ interfaces in the three-dimensional mesoporous structure.

A comparison of catalyst activity with other Ni-based catalysts found in the literature is listed in Table 3. Compared with the Ni-based catalysts reported in the literature, the $50 \% \mathrm{Ni}-\mathrm{CeO}_{2}-\mathrm{CSC}$ catalyst exhibits an excellent $\mathrm{CO}_{2}$ conversion rate in low-temperature $\mathrm{CO}_{2}$ methanation.

Table 3. $\mathrm{CO}_{2}$ conversion rate and $\mathrm{CH}_{4}$ selectivity of the $50 \% \mathrm{Ni}-\mathrm{CeO}_{2}-\mathrm{CSC}$ catalyst and recently reported low-temperature $\mathrm{CO}_{2}$ methanation catalysts in the literature at $0.1 \mathrm{MPa}$.

\begin{tabular}{|c|c|c|c|c|c|}
\hline Catalyst & $\begin{array}{c}\text { WHSV } \\
\left(\mathrm{mL} \cdot \mathrm{g}_{\mathrm{cat}}{ }^{-1} \cdot \mathrm{h}^{-1}\right)\end{array}$ & $\begin{array}{c}\text { Reaction } \\
\text { Temperature }\left({ }^{\circ} \mathrm{C}\right)\end{array}$ & $\mathrm{X}_{\mathrm{CO} 2}(\%)$ & $\begin{array}{c}\mathrm{CO}_{2} \text { Conversion } \\
\text { Rate }\left(\times 10^{-5}\right. \\
\left.\mathrm{mol}_{\mathrm{CO}_{2}} / \mathrm{g}_{\mathrm{cat}} / \mathrm{s}\right)\end{array}$ & Ref. \\
\hline \multirow{2}{*}{$50 \% \mathrm{Ni}-\mathrm{CeO}_{2}-\mathrm{CSC}$} & 120,000 & 250 & 33 & 4.91 & This Work \\
\hline & & 300 & 70 & 10.42 & This Work \\
\hline \multirow[t]{2}{*}{$20 \% \mathrm{Ni}-\mathrm{Ce} / \mathrm{RGO}$} & 36,000 & 250 & 20 & 1.79 & [40] \\
\hline & & 300 & 80 & 7.14 & [40] \\
\hline \multirow[t]{2}{*}{$25 \% \mathrm{Ni} / \mathrm{Al}_{2} \mathrm{O}_{3}$} & 9000 & 250 & 7 & 0.17 & [41] \\
\hline & & 300 & 50 & 1.24 & [41] \\
\hline \multirow[t]{2}{*}{$15 \% \mathrm{Ni} / \mathrm{ZrO}_{2}$} & 48,000 & 250 & 15 & 1.61 & [42] \\
\hline & & 300 & 60 & 6.43 & [42] \\
\hline \multirow[t]{2}{*}{$10 \% \mathrm{Ni} / \mathrm{CeO}_{2}-\mathrm{ZrO}_{2}$} & 20,000 & 250 & 46 & 0.91 & [43] \\
\hline & & 300 & 55 & 1.09 & [43] \\
\hline $6 \% \mathrm{Ni} / \mathrm{ZrO}_{2}$ & 15,000 & 250 & 84 & 2.50 & [11] \\
\hline $6 \% \mathrm{Ni}-\mathrm{MgO} / \mathrm{ZrO}_{2}$ & 15,000 & 250 & 90 & 2.68 & [11] \\
\hline
\end{tabular}

The stability test of the $50 \% \mathrm{Ni}-\mathrm{CeO}_{2}-\mathrm{CSC}$ catalyst was conducted at 300 and $350{ }^{\circ} \mathrm{C}$, and the results are shown in Figure 7. The catalytic performance was stable for $50 \mathrm{~h}$, and the $\mathrm{CO}_{2}$ conversions at 300 and $350{ }^{\circ} \mathrm{C}$ remained around $68 \%$ and $82 \%$, respectively. The $\mathrm{CH}_{4}$ selectivity was higher than $99 \%$. The results show that the $50 \% \mathrm{Ni}-\mathrm{CeO}_{2}-\mathrm{CSC}$ catalyst has good stability. The embedded structure of the $50 \% \mathrm{Ni}-\mathrm{CeO}_{2}-\mathrm{CSC}$ catalyst can prevent the sintering or aggregation of the highly dispersed $\mathrm{Ni}$ during the methanation reaction, thus improving the stability of the catalyst. The excellent stability of the catalyst could be due to the pore wall embedded structure of the catalyst. 

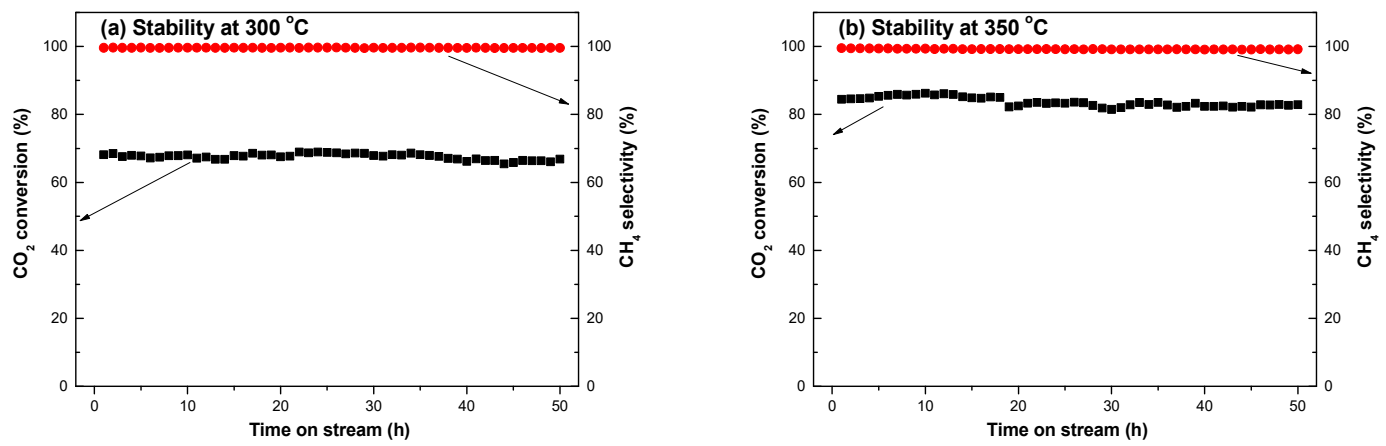

Figure 7. Stability of the $50 \% \mathrm{Ni}-\mathrm{CeO}_{2}-\mathrm{CSC}$ in $\mathrm{CO}_{2}$ methanation: (a) stability at $300{ }^{\circ} \mathrm{C},(\mathbf{b})$ stability at $350{ }^{\circ} \mathrm{C}$.

\subsection{Characterization of the Used Catalyst}

The $50 \% \mathrm{Ni}-\mathrm{CeO}_{2}-\mathrm{CSC}$ catalyst after the stability test at $300{ }^{\circ} \mathrm{C}$ was characterized by TEM and XRD. The three-dimensional mesoporous structure with the spherical pores of the catalyst is clearly visible in Figure 8a. As can be seen from the high-resolution TEM image (Figure 8b), $\mathrm{Ni}$ and $\mathrm{CeO}_{2}$ particles less than $5 \mathrm{~nm}$ constituted the pore wall, and the metal Ni particles were embedded in the pore wall and in close contact with $\mathrm{CeO}_{2}$. The TEM results show that the mesoporous structure and particle size did not change significantly, which further confirms the stability of the three-dimensional mesoporous structure. The XRD pattern of the used $50 \% \mathrm{Ni}-\mathrm{CeO}_{2}-\mathrm{CSC}$ catalyst is shown in Figure 8c: the $\mathrm{Ni}$ and $\mathrm{CeO}_{2}$ peaks are broad and very weak, indicating that the $\mathrm{Ni}$ and $\mathrm{CeO}_{2}$ particles were small and stable in the $50 \% \mathrm{Ni}^{-} \mathrm{CeO}_{2}-\mathrm{CSC}$ catalyst during the methanation reaction. This result further confirms that the three-dimensional embedded structure can prevent the small nickel particles from sintering or aggregating, thus making the catalyst stable in the $\mathrm{CO}_{2}$ methanation reaction.

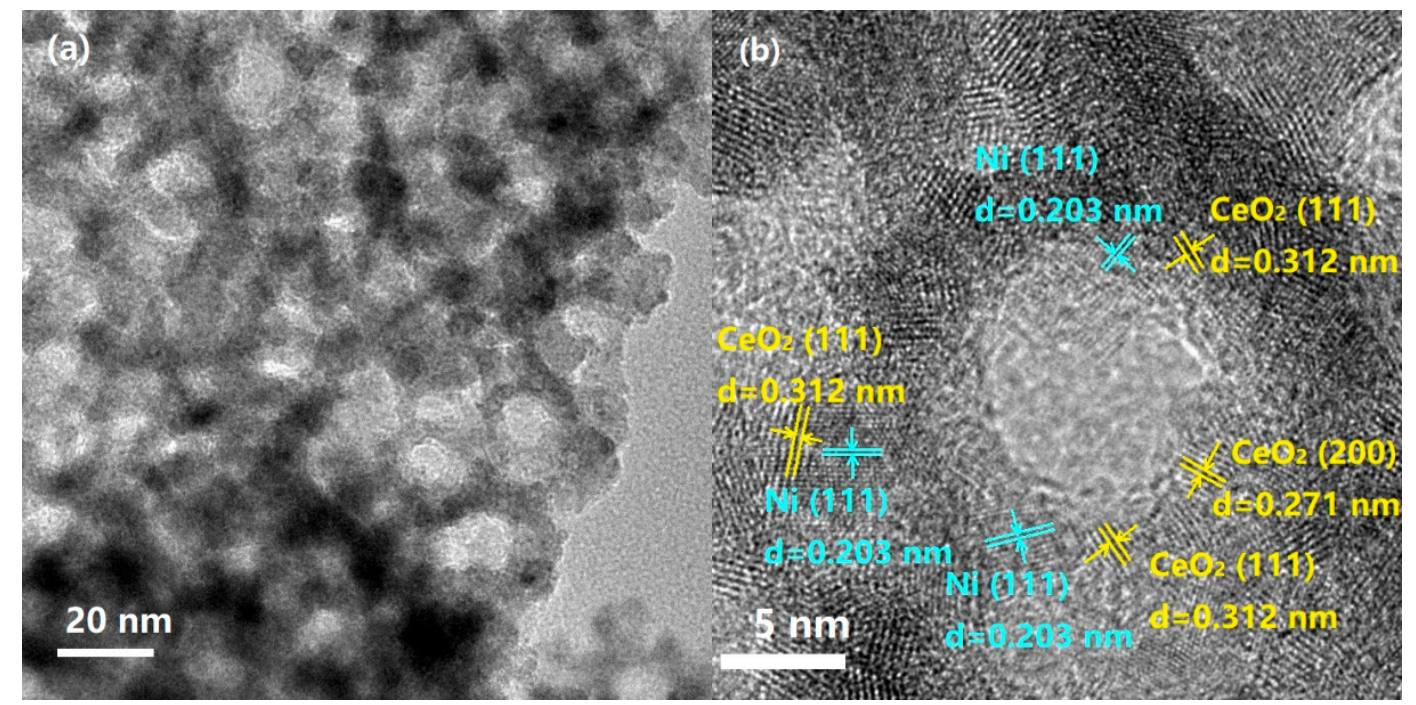

Figure 8. Cont. 


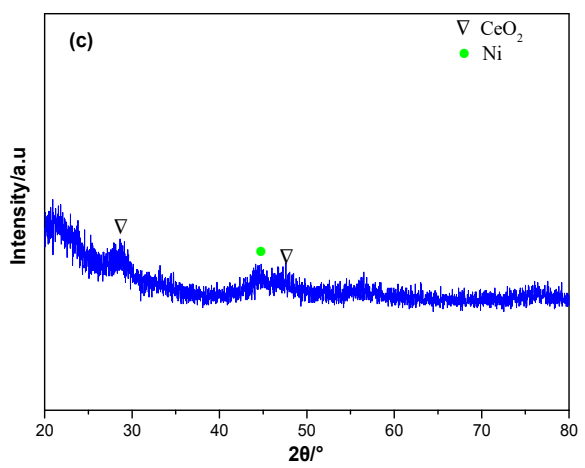

Figure 8. (a,b) Transmission electron microscopy images and (c) X-ray diffraction pattern of the used $50 \% \mathrm{Ni}-\mathrm{CeO}_{2}-\mathrm{CSC}$ catalyst.

\section{Experimental}

\subsection{Synthesis of Catalysts}

A series of $\mathrm{Ni}-\mathrm{CeO}_{2}-\mathrm{CSC}$ catalysts were prepared with the CSC method, as shown in Scheme 1. In the solution combustion reaction, metal nitrates were used as the oxidizers, and glycine as the fuel. When preparing $1 \mathrm{~g} \mathrm{Ni}-\mathrm{CeO}_{2}-\mathrm{CSC}$ catalyst, $0.6 \mathrm{~g}$ glycine and an amount of $\mathrm{Ce}\left(\mathrm{NO}_{3}\right)_{2} \cdot 6 \mathrm{H}_{2} \mathrm{O}$, $\mathrm{Ni}\left(\mathrm{NO}_{3}\right)_{2} \cdot 6 \mathrm{H}_{2} \mathrm{O}$ were dissolved in $6.3 \mathrm{~mL}$ deionized water, and the solution was ultrasonic for $20 \mathrm{~min}$. A $1.26 \mathrm{~mL}$ colloidal $\mathrm{SiO}_{2}$ LUDOX TMA (Sigma-Aldrich, Saint Louis, USA; $34 \mathrm{wt} \%$, diameter of $22 \mathrm{~nm}$ ) was added to the solution and continued to be ultrasonic for $20 \mathrm{~min}$. Then, the solution was heated over a hot plate at $210^{\circ} \mathrm{C}$. After a few minutes of evaporation, a combustion reaction occurred, releasing large amounts of gas and forming a solid powder. The powder was calcined at $450{ }^{\circ} \mathrm{C}$ in air for $4 \mathrm{~h}$, and was then treated with a $2 \mathrm{M} \mathrm{NaOH}$ solution at $80^{\circ} \mathrm{C}$ for $4 \mathrm{~h}$. After washing with ethanol and water 3 times and drying for $12 \mathrm{~h}$ at $80^{\circ} \mathrm{C}$, the catalyst was obtained and named as $\mathrm{xNi}^{-} \mathrm{CeO}_{2}-\mathrm{CSC}$, where $\mathrm{x}$ represents the weight percentage of the nickel. Three catalysts with nickel content of $20 \%, 50 \%$ and $80 \%$ were prepared. A pure $\mathrm{NiO}$ catalyst, denoted as Ni-CSC, was prepared with the same method.

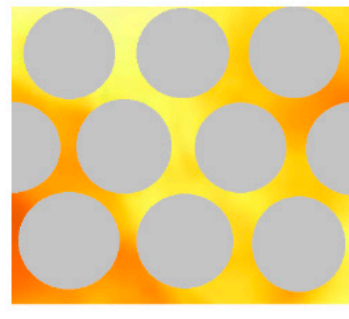

Combustion

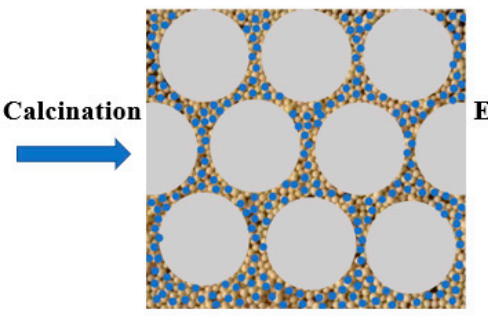

Scheme 1. Synthesis route of the $\mathrm{Ni}-\mathrm{CeO}_{2}-\mathrm{CSC}$ catalysts

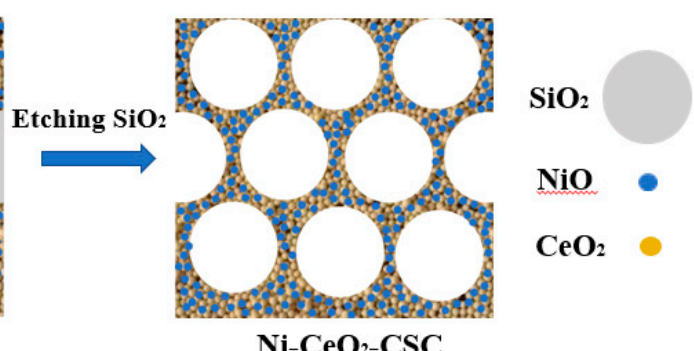

$\mathrm{Ni}-\mathrm{CeO}_{2}-\mathrm{CSC}$

The $50 \% \mathrm{Ni}-\mathrm{CeO}_{2}-\mathrm{CP}$ catalyst was prepared with a coprecipitation method. An $\mathrm{NaOH}$ solution was fed dropwise into an aqueous mixture of $\mathrm{Ce}\left(\mathrm{NO}_{3}\right)_{2}$ and $\mathrm{Ni}\left(\mathrm{NO}_{3}\right)_{2}$ until the $\mathrm{pH}$ of the mixture was 10. The mixture was aged at room temperature for $24 \mathrm{~h}$. The obtained precipitate was filtered and washed with water, and then dried at $80{ }^{\circ} \mathrm{C}$ for $12 \mathrm{~h}$. Finally, the $50 \% \mathrm{Ni}^{-} \mathrm{CeO}_{2}-\mathrm{CP}$ was obtained by calcining the precipitate at $450^{\circ} \mathrm{C}$ for $4 \mathrm{~h}$.

\subsection{Characterization of Catalysts}

The $\mathrm{N}_{2}$ isotherms of the calcined catalyst were performed at $-196{ }^{\circ} \mathrm{C}$ on a gas sorption instrument (Quantachrome, Autosorb-iQ). Before the test, the sample was degassed at $300{ }^{\circ} \mathrm{C}$ for $8 \mathrm{~h}$. The Brunauer-Emmett-Teller (BET) method was used to calculate the specific surface area. The pore size 
distribution was calculated from the quenched solid density functional theory (QSDFT) method using the calculation model of $\mathrm{N}_{2}$ adsorbed on carbon (slit/cylindrical/spherical pores, adsorption branch).

The X-ray diffractometer (XRD) experiments were conducted on a powder X-ray diffractometer (DX-2700, Haoyuan Corporation, Dandong, China) with a $\mathrm{Cu} \mathrm{K} \alpha$ anode. The transmission electron microscopy (TEM) experiments were performed on a Tecnai G2 F20 microscope (FEI Company, Hillsboro, OR, USA) at $200 \mathrm{kV}$. The $\mathrm{H}_{2}$ temperature programmed reduction was performed on a TP-5080 apparatus (Xianquan, Tianjin, China) using 5\% $\mathrm{H}_{2} / \operatorname{Ar}\left(30 \mathrm{~mL} \mathrm{~min}^{-1}\right)$.

\subsection{Catalytic Performance}

The catalytic test was performed in a fixed-bed quartz reactor $(8 \mathrm{~mm}$ i.d.) at $0.1 \mathrm{MPa}$. Before the reaction, a $50 \mathrm{mg}$ sample mixed with $200 \mathrm{mg}$ inert silica was reduced at $450{ }^{\circ} \mathrm{C}$ for $40 \mathrm{~min}$ with $20 \% \mathrm{H}_{2} / \mathrm{Ar}\left(50 \mathrm{~mL} \mathrm{~min}^{-1}\right)$. The reaction feed was a mixed gas $\left(\mathrm{CO}_{2} / \mathrm{H}_{2} / \mathrm{Ar}=1 / 4 / 5,100 \mathrm{~mL} \mathrm{~min}^{-1}\right)$. The weight hourly space velocity (WHSV) was $120,000 \mathrm{~mL} \mathrm{~g}_{\mathrm{cat}}{ }^{-1} \mathrm{~h}^{-1}$. The Ar was used as the internal standard gas for calculating the $\mathrm{CO}_{2}$ conversion. After the removal of the water by a cold trap, at each rection temperature, the exit gases were sampled and analyzed four times by gas chromatography (Techcomp GC-7900) with an error of less than $2 \%$.

\section{Conclusions}

In this study, three-dimensional mesoporous $\mathrm{Ni}-\mathrm{CeO}_{2}-\mathrm{CSC}$ catalysts with different $\mathrm{Ni}$ contents, prepared using the $\mathrm{CSC}$ method, were used for $\mathrm{CO}_{2}$ methanation. The $\mathrm{Ni}-\mathrm{CeO}_{2}-\mathrm{CSC}$ catalysts had high $\mathrm{S}_{\mathrm{BETs}}$. In the $\mathrm{Ni}-\mathrm{CeO}_{2}-\mathrm{CSC}$ catalysts, small $\mathrm{Ni}$ particles were embedded in the pore walls which interacted with $\mathrm{CeO}_{2}$. This special embedded structure enables the catalyst to have more $\mathrm{Ni}-\mathrm{CeO}_{2}$ interface, while maintaining a particle size of less than $5 \mathrm{~nm}$, even when the nickel content reaches $50 \%$. Among the $\mathrm{Ni}-\mathrm{CeO}_{2}-\mathrm{CSC}$ catalysts with different nickel contents, the $50 \% \mathrm{Ni}-\mathrm{CeO}_{2}-\mathrm{CSC}$ catalyst showed the best catalytic performance. Compared to the $50 \% \mathrm{Ni}-\mathrm{CeO}_{2}-\mathrm{CP}$ catalyst, the $50 \%$ $\mathrm{Ni}-\mathrm{CeO}_{2}-\mathrm{CSC}$ catalyst had a higher $\mathrm{CO}_{2}$ conversion and $\mathrm{CH}_{4}$ selectivity due to its smaller Ni particle size and more $\mathrm{Ni}-\mathrm{CeO}_{2}$ interface. In addition, the $50 \% \mathrm{Ni}-\mathrm{CeO}_{2}-\mathrm{CSC}$ catalyst exhibited excellent stability due to the confinement effect of the embedded structure.

Author Contributions: Conceptualization, L.W.; data curation, J.H.; formal analysis, L.W., J.H., H.L., Q.W., D.G., L.M., H.T. and C.Z.; funding acquisition, L.W.; investigation, L.W. and J.H.; writing-original draft, L.W., J.H. and H.L.; writing-review and editing, H.L., Q.W. and D.G. All authors have read and agreed to the published version of the manuscript.

Funding: This research was funded by the Fundamental Research Funds for Zhejiang Provincial Universities and Research Institutes (No. 2019JZ00003) and the Science and Technology Foundation of Zhoushan (No. 2018C21013).

Conflicts of Interest: The authors declare no conflict of interest.

\section{References}

1. Ma, J.; Sun, N.; Zhang, X.; Zhao, N.; Xiao, F.; Wei, W.; Sun, Y. A short review of catalysis for $\mathrm{CO}_{2}$ conversion. Catal. Today 2009, 148, 221-231. [CrossRef]

2. Zheng, Y.; Zhang, W.; Li, Y.; Chen, J.; Yu, B.; Wang, J.; Zhang, L.; Zhang, J. Energy related $\mathrm{CO}_{2}$ conversion and utilization: Advanced materials/nanomaterials, reaction mechanisms and technologies. Nano Energy 2017, 40, 512-539. [CrossRef]

3. Frontera, P.; Macario, A.; Ferraro, M.; Antonucci, P. Supported Catalysts for $\mathrm{CO}_{2}$ Methanation: A Review. Catalysts 2017, 7, 59. [CrossRef]

4. Lee, W.J.; Li, C.; Prajitno, H.; Yoo, J.; Patel, J.; Yang, Y.; Lim, S. Recent trend in thermal catalytic low temperature $\mathrm{CO}_{2}$ methanation: A critical review. Catal. Today 2020, in press. [CrossRef]

5. Martin, N.M.; Hemmingsson, F.; Schaefer, A.; Ek, M.; Merte, L.R.; Hejral, U.; Gustafson, J.; Skoglundh, M.; Dippel, A.-C.; Gutowski, O.; et al. Structure-function relationship for $\mathrm{CO}_{2}$ methanation over ceria supported Rh and Ni catalysts under atmospheric pressure conditions. Catal. Sci. Technol. 2019, 9, 1644-1653. [CrossRef] 
6. Xu, J.; Lin, Q.; Su, X.; Duan, H.; Geng, H.; Huang, Y. $\mathrm{CO}_{2}$ methanation over $\mathrm{TiO}_{2}-\mathrm{Al}_{2} \mathrm{O}_{3}$ binary oxides supported Ru catalysts. Chin. J. Chem. Eng. 2016, 24, 140-145. [CrossRef]

7. Kim, A.; Debecker, D.P.; Devred, F.; Dubois, V.; Sanchez, C.; Sassoye, C. $\mathrm{CO}_{2}$ methanation on $\mathrm{Ru} / \mathrm{TiO} 2$ catalysts: On the effect of mixing anatase and rutile $\mathrm{TiO}_{2}$ supports. Appl. Catal. B Environ. 2018, 220, 615-625. [CrossRef]

8. Jiang, H.; Gao, Q.; Wang, S.; Chen, Y.; Zhang, M. The synergistic effect of Pd NPs and UiO-66 for enhanced activity of carbon dioxide methanation. J. $\mathrm{CO}_{2}$ Util. 2019, 31, 167-172. [CrossRef]

9. Jia, X.; Zhang, X.; Rui, N.; Hu, X.; Liu, C.-J. Structural effect of $\mathrm{Ni} / \mathrm{ZrO}_{2}$ catalyst on $\mathrm{CO}_{2}$ methanation with enhanced activity. Appl. Catal. B Environ. 2019, 244, 159-169. [CrossRef]

10. Vrijburg, W.L.; Garbarino, G.; Chen, W.; Parastaev, A.; Longo, A.; Pidko, E.A.; Hensen, E.J.M. Ni-Mn catalysts on silica-modified alumina for $\mathrm{CO}_{2}$ methanation. J. Catal. 2020, 382, 358-371. [CrossRef]

11. Tan, J.; Wang, J.; Zhang, Z.; Ma, Z.; Wang, L.; Liu, Y. Highly dispersed and stable Ni nanoparticles confined by $\mathrm{MgO}$ on $\mathrm{ZrO}_{2}$ for $\mathrm{CO}_{2}$ methanation. Appl. Surf. Sci. 2019, 481, 1538-1548. [CrossRef]

12. Tang, G.; Gong, D.; Liu, H.; Wang, L. Highly Loaded Mesoporous $\mathrm{Ni}-\mathrm{La}_{2} \mathrm{O}_{3}$ Catalyst Prepared by Colloidal Solution Combustion Method for $\mathrm{CO}_{2}$ Methanation. Catalysts 2019, 9, 442. [CrossRef]

13. Millet, M.-M.; Tarasov, A.V.; Girgsdies, F.; Algara-Siller, G.; Schlögl, R.; Frei, E. Highly Dispersed $\mathrm{Ni}^{0} / \mathrm{Ni}_{\mathrm{x}} \mathrm{Mg}_{1-\mathrm{x}} \mathrm{O}$ Catalysts Derived from Solid Solutions: How Metal and Support Control the $\mathrm{CO}_{2}$ Hydrogenation. ACS Catal. 2019, 9, 8534-8546. [CrossRef]

14. Zeng, L.; Wang, Y.; Li, Z.; Song, Y.; Zhang, J.; Wang, J.; He, X.; Wang, C.; Lin, W. Highly Dispersed Ni Catalyst on Metal-Organic Framework-Derived Porous Hydrous Zirconia for $\mathrm{CO}_{2}$ Methanation. ACS Appl. Mater. Interfaces 2020. [CrossRef] [PubMed]

15. Bukhari, S.N.; Chong, C.C.; Teh, L.P.; Vo, D.-V.N.; Ainirazali, N.; Triwahyono, S.; Jalil, A.A.; Setiabudi, H.D. Promising hydrothermal technique for efficient $\mathrm{CO}_{2}$ methanation over Ni/SBA. Int. J. Hydrog. Energy 2019, 44, 20792-20804. [CrossRef]

16. Bacariza, M.C.; Graça, I.; Bebiano, S.S.; Lopes, J.M.; Henriques, C. Micro- and mesoporous supports for $\mathrm{CO}_{2}$ methanation catalysts: A comparison between SBA-15, MCM-41 and USY zeolite. Chem. Eng. Sci. 2018, 175, 72-83. [CrossRef]

17. Guo, X.; Traitangwong, A.; Hu, M.; Zuo, C.; Meeyoo, V.; Peng, Z.; Li, C. Carbon Dioxide Methanation over Nickel-Based Catalysts Supported on Various Mesoporous Material. Energy Fuels 2018, 32, 3681-3689. [CrossRef]

18. Guo, M.; $\mathrm{Lu}, \mathrm{G}$. The effect of impregnation strategy on structural characters and $\mathrm{CO}_{2}$ methanation properties over $\mathrm{MgO}$ modified $\mathrm{Ni} / \mathrm{SiO}_{2}$ catalysts. Catal. Commun. 2014, 54, 55-60. [CrossRef]

19. Chen, Y.; Qiu, B.; Liu, Y.; Zhang, Y. An active and stable nickel-based catalyst with embedment structure for $\mathrm{CO}_{2}$ methanation. Appl. Catal. B Environ. 2020, 269, 118801. [CrossRef]

20. Zhen, W.; Li, B.; Lu, G.; Ma, J. Enhancing catalytic activity and stability for $\mathrm{CO}_{2}$ methanation on Ni@MOF-5 via control of active species dispersion. Chem. Commun. 2015, 51, 1728-1731. [CrossRef]

21. Mihet, M.; Grad, O.; Blanita, G.; Radu, T.; Lazar, M.D. Effective encapsulation of Ni nanoparticles in metal-organic frameworks and their application for $\mathrm{CO}_{2}$ methanation. Int. J. Hydrog. Energy 2019, 44, 13383-13396. [CrossRef]

22. Lin, X.; Wang, S.; Tu, W.; Hu, Z.; Ding, Z.; Hou, Y.; Xu, R.; Dai, W. MOF-derived hierarchical hollow spheres composed of carbon-confined Ni nanoparticles for efficient $\mathrm{CO}_{2}$ methanation. Catal. Sci. Technol. 2019, 9, 731-738. [CrossRef]

23. De Rogatis, L.; Cargnello, M.; Gombac, V.; Lorenzut, B.; Montini, T.; Fornasiero, P. Embedded Phases: A Way to Active and Stable Catalysts. ChemSusChem 2010, 3, 24-42. [CrossRef] [PubMed]

24. Wang, Y.; Zhao, H.; Zhao, G. Iron-copper bimetallic nanoparticles embedded within ordered mesoporous carbon as effective and stable heterogeneous Fenton catalyst for the degradation of organic contaminants. Appl. Catal. B Environ. 2015, 164, 396-406. [CrossRef]

25. Zhang, X.; Zhang, L.; Peng, H.; You, X.; Peng, C.; Xu, X.; Liu, W.; Fang, X.; Wang, Z.; Zhang, N.; et al. Nickel nanoparticles embedded in mesopores of AlSBA-15 with a perfect peasecod-like structure: A catalyst with superior sintering resistance and hydrothermal stability for methane dry reforming. Appl. Catal. B Environ. 2018, 224, 488-499. [CrossRef]

26. Liu, Q.; Tian, Y. One-pot synthesis of NiO/SBA-15 monolith catalyst with a three-dimensional framework for $\mathrm{CO}_{2}$ methanation. Int. J. Hydrog. Energy 2017, 42, 12295-12300. [CrossRef] 
27. Yu, Y.; Cao, C.Y.; Chen, Z.; Liu, H.; Li, P.; Dou, Z.F.; Song, W.G. Au nanoparticles embedded into the inner wall of $\mathrm{TiO}_{2}$ hollow spheres as a nanoreactor with superb thermal stability. Chem. Commun. 2013, 49, 3116-3118. [CrossRef]

28. Li, M.; Amari, H.; van Veen, A.C. Metal-oxide interaction enhanced $\mathrm{CO}_{2}$ activation in methanation over ceria supported nickel nanocrystallites. Appl. Catal. B Environ. 2018, 239, 27-35. [CrossRef]

29. Atzori, L.; Cutrufello, M.G.; Meloni, D.; Monaci, R.; Cannas, C.; Gazzoli, D.; Sini, M.F.; Deiana, P.; Rombi, E. $\mathrm{CO}_{2}$ methanation on hard-templated $\mathrm{NiO}-\mathrm{CeO}_{2}$ mixed oxides. Int. J. Hydrog. Energy 2017, 42, 20689-20702. [CrossRef]

30. Zhou, G.; Liu, H.; Cui, K.; Xie, H.; Jiao, Z.; Zhang, G.; Xiong, K.; Zheng, X. Methanation of carbon dioxide over $\mathrm{Ni} / \mathrm{CeO}_{2}$ catalysts: Effects of support $\mathrm{CeO}_{2}$ structure. Int. J. Hydrog. Energy 2017, 42, 16108-16117. [CrossRef]

31. Bian, Z.; Chan, Y.M.; Yu, Y.; Kawi, S. Morphology dependence of catalytic properties of Ni/CeO $\mathrm{C}_{2}$ for $\mathrm{CO}_{2}$ methanation: A kinetic and mechanism study. Catal. Today 2018. [CrossRef]

32. Ye, R.-P.; Li, Q.; Gong, W.; Wang, T.; Razink, J.J.; Lin, L.; Qin, Y.-Y.; Zhou, Z.; Adidharma, H.; Tang, J.; et al. High-performance of nanostructured $\mathrm{Ni} / \mathrm{CeO}_{2}$ catalyst on $\mathrm{CO}_{2}$ methanation. Appl. Catal. B Environ. 2020, 268, 118474. [CrossRef]

33. Voskanyan, A.A.; Chan, K.-Y.; Li, C.-Y.V. Colloidal Solution Combustion Synthesis: Toward Mass Production of a Crystalline Uniform Mesoporous $\mathrm{CeO}_{2}$ Catalyst with Tunable Porosity. Chem. Mater. 2016, 28, 2768-2775. [CrossRef]

34. Voskanyan, A.A.; Ho, C.-K.; Chan, K.Y. 3D $\delta-\mathrm{MnO}_{2}$ nanostructure with ultralarge mesopores as high-performance lithium-ion battery anode fabricated via colloidal solution combustion synthesis. J. Power Sources 2019, 421, 162-168. [CrossRef]

35. Wang, L.; Liu, H. Mesoporous $\mathrm{Co}-\mathrm{CeO}_{2}$ catalyst prepared by colloidal solution combustion method for reverse water-gas shift reaction. Catal. Today 2018, 316, 155-161. [CrossRef]

36. Shan, W.; Luo, M.; Ying, P.; Shen, W.; Li, C. Reduction property and catalytic activity of $\mathrm{Ce}_{1-\mathrm{X}} \mathrm{Ni}_{X} \mathrm{O}_{2}$ mixed oxide catalysts for $\mathrm{CH}_{4}$ oxidation. Appl. Catal. A Gen. 2003, 246, 1-9. [CrossRef]

37. Das, S.; Ashok, J.; Bian, Z.; Dewangan, N.; Wai, M.H.; Du, Y.; Borgna, A.; Hidajat, K.; Kawi, S. Silica-Ceria sandwiched $\mathrm{Ni}$ core-shell catalyst for low temperature dry reforming of biogas: Coke resistance and mechanistic insights. Appl. Catal. B Environ. 2018, 230, 220-236. [CrossRef]

38. Li, S.; Liu, G.; Zhang, S.; An, K.; Ma, Z.; Wang, L.; Liu, Y. Cerium-modified Ni-La $\mathrm{O}_{3} / \mathrm{ZrO}_{2}$ for $\mathrm{CO}_{2}$ methanation. J. Energy Chem. 2020, 43, 155-164. [CrossRef]

39. Xu, L.; Wang, F.; Chen, M.; Nie, D.; Lian, X.; Lu, Z.; Chen, H.; Zhang, K.; Ge, P. CO 2 methanation over rare earth doped $\mathrm{Ni}$ based mesoporous catalysts with intensified low-temperature activity. Int. J. Hydrog. Energy 2017, 42, 15523-15539. [CrossRef]

40. Hu, F.; Tong, S.; Lu, K.; Chen, C.-M.; Su, F.-Y.; Zhou, J.; Lu, Z.-H.; Wang, X.; Feng, G.; Zhang, R. Reduced graphene oxide supported Ni-Ce catalysts for $\mathrm{CO}_{2}$ methanation: The support and ceria promotion effects. J. $\mathrm{CO}_{2}$ Util. 2019, 34, 676-687. [CrossRef]

41. Daroughegi, R.; Meshkani, F.; Rezaei, M. Enhanced activity of $\mathrm{CO}_{2}$ methanation over mesoporous nanocrystalline $\mathrm{Ni}-\mathrm{Al}_{2} \mathrm{O}_{3}$ catalysts prepared by ultrasound-assisted co-precipitation method. Int. J. Hydrog. Energy 2017, 42, 15115-15125. [CrossRef]

42. Zhao, K.; Wang, W.; Li, Z. Highly efficient $\mathrm{Ni} / \mathrm{ZrO}_{2}$ catalysts prepared via combustion method for $\mathrm{CO}_{2}$ methanation. J. $\mathrm{CO}_{2}$ Util. 2016, 16, 236-244. [CrossRef]

43. Ashok, J.; Ang, M.L.; Kawi, S. Enhanced activity of $\mathrm{CO}_{2}$ methanation over $\mathrm{Ni} / \mathrm{CeO}_{2}-\mathrm{ZrO}_{2}$ catalysts: Influence of preparation methods. Catal. Today 2017, 281, 304-311. [CrossRef]

(C) 2020 by the authors. Licensee MDPI, Basel, Switzerland. This article is an open access article distributed under the terms and conditions of the Creative Commons Attribution (CC BY) license (http://creativecommons.org/licenses/by/4.0/). 